\title{
Why Londoners have low death rates from ischaemic heart disease and stroke
}

\author{
D J P Barker, C Osmond, B Pannett
}

\begin{abstract}
Objective-To explain the low death rates from cardiovascular disease in London.

Setting-London and the other counties of England and Wales.

Subjects-Women living in London during 1901-10 and people in London dying during 1968-78.

Results - At the beginning of the twentieth century young women aged 15-34 in London had remarkably low death rates, largely because of low rates for tuberculosis and other infectious diseases and low mortality during childbirth. Their low death rates contrasted with the high rates in girls under 15 years.

Conclusions-Large numbers of young women had migrated into London from agricultural counties in southern England and went into domestic service, where the diet was usually very good. Recent findings suggest that a mother's nutrition and health has a major effect on the risk of cardiovascular disease in the next generation. The low cardiovascular mortality in London is consistent with this, and contrasts with the high mortality from other common diseases.
\end{abstract}

\section{Introduction}

For more than a hundred years, people living in the cities and large towns of Britain have had higher death rates than people living in small towns and villages.' London is an exception. During 1980-5, for example, age standardised death rates from all causes in London, expressed in relation to a national average of 100 , were 96 among men and 93 among women. These low standardised mortality ratios in London resulted largely from low rates of cardiovascular disease. Ratios for ischaemic heart disease were 90 in men and 87 in women; ratios for stroke were 78 in each sex. Londoners' low cardiovascular death rates have never been explained.

The geographical distribution of national death rates during 1968-78 has been analysed in unusual detail. ${ }^{2}$ During this period, mortality ratios in London for ischaemic heart disease and stroke combined were 87 in men and 83 in women. In none of the 33 London boroughs was cardiovascular mortality above the national average in either men or women. London's low cardiovascular mortality contrasts with above average mortality from diseases associated with poor socioeconomic conditions, cigarette smoking, and alcohol consumption. Standardised mortality ratios for chronic bronchitis during 1968-78 were 105 in men and 111 in women; for lung cancer, 114 and 127; for cirrhosis of the liver, 101 and 103; for suicide, 115 and 130. In only four of the 33 boroughs were lung cancer death rates below the national average, the lowest standardised mortality ratio being 92 . Thus the lifestyle of Londoners does not seem especially healthy and is not consistent with their remarkably low death rates from cardiovascular disease.
In this paper we propose that the origins of London's good health lie in the good nutrition and health of its mothers and infants at the beginning of the century. Recent findings suggest that good maternal, fetal, and infant nutrition is associated with lower rates of cardiovascular disease in the next generation. Follow up studies of men and women born in three areas of Britain (Hertfordshire, Preston, and Sheffield) 50 and more years ago show that those who were small at birth or at one year have high death rates from cardiovascular disease, ${ }^{34}$ high prevalence of impaired glucose tolerance and diabetes, ${ }^{56}$ raised blood pressure ${ }^{78}$ increased concentrations of fibrinogen and factor VII, ${ }^{9}$ abnormal plasma lipids, ${ }^{10} 11$ and a tendency to store fat abdominally. ${ }^{12}$ The associations are not seen only in babies with growth retardation defined by the lowest centiles of weight at birth and during infancy. They are seen in babies within the normal range of weight. Some are thin; some are small at birth in relation to the size of their placenta; some have above average birth weight but are short and have reduced weight gain in infancy. The associations between early growth and adult disorders are strong and independent of influences on adult lifestyle such as cigarette smoking and obesity. They are thought to reflect the long term "programming" of abnormal physiology and metabolism by impaired development of tissues and organs including blood vessels, the liver, and pancreas at critical stages of early life. ${ }^{13}$

Maternal nutrition is thought to have an important influence on early programming. ${ }^{13}$ In the early years of this century London had low rates of maternal and neonatal mortality. For example, maternal mortality during $1911-4$ was $3 \cdot 1$ per 1000 births compared with 4.0 in England and Wales. Neonatal mortality was 33 per 1000 births compared with $39 .^{\prime}$ In the past, maternal mortality was low in places where women had good physique, nutrition, and health, ${ }^{14}$ and neonatal mortality was low where few babies had low birth weight. ${ }^{15}$ The low maternal and neonatal mortality in London therefore implies that at the beginning of this century its women had good physique, health, and nutrition, which is surprising. It conflicts with the picture of London presented by novelists and with detailed descriptions of life in London given by the surveys which Charles Booth carried out from 1886 onwards. Writing of the London poor, he said, "Their life is the life of savages with vicissitudes of extreme hardship and occasional excess. Their food is of the coarsest description, and their only luxury is drink."16 Amid this savagery, pregnancy, childbirth, and early infancy were unusually safe for both the mother and the baby. Why?

\section{Methods}

The Office of Population Censuses and Surveys made available extracts from all death certificates in England and Wales during 1968-78, the period covered 
by the eighth revision of the International Classification of Diseases (ICD). Rates for each area were based on population data from the 1971 census. ${ }^{2}$ We defined London using the boundaries that applied at the 1971 census. Death rates specific for age and cause for 1901-10 were taken from the summary tables of the registrar general's reports for England and Wales. ${ }^{17}$ The age structure of the population, place of birth, marital status, and employment were taken from the 1911 census. ${ }^{18-20}$ People born during 1901-10 are of the generation that died during 1968-78.

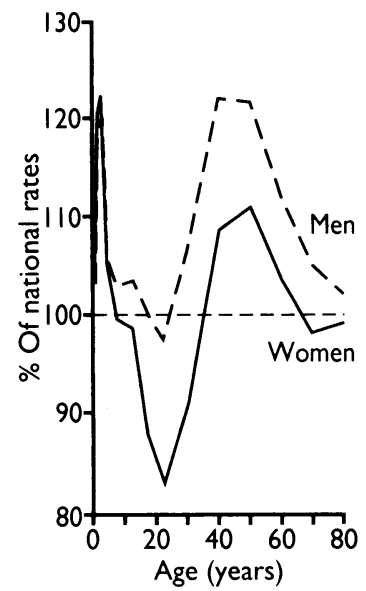

FIG 1-Age specific death rates in London, 1901-10, expressed as a percentage of national rates for England and Wales

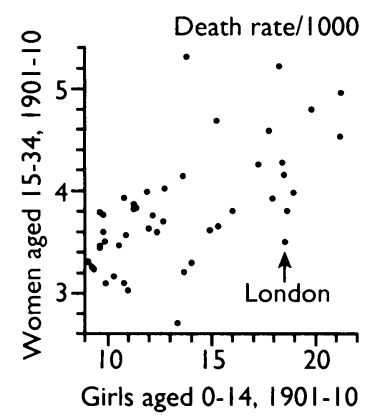

FIG 2-Death rates among girls under 15 years and women aged 15 to 34 years in the counties of England and Wales, 1901-10

TABLE II - Standardised mortality ratios for lobar pneumonia among women in London, 1906-10

\begin{tabular}{cc}
\hline $\begin{array}{c}\text { Age } \\
\text { (years) }\end{array}$ & $\begin{array}{c}\text { Standardised } \\
\text { mortality ratios }\end{array}$ \\
\hline $0-$ & 132 \\
$5-$ & 102 \\
$10-$ & 107 \\
$15-$ & 82 \\
$20-$ & 77 \\
$25-$ & 82 \\
$35-$ & 113 \\
$45-$ & 127 \\
$55-$ & 132 \\
$65-$ & 136 \\
$75-$ & 141 \\
$85-$ & 165 \\
\hline All ages & 120 \\
\hline
\end{tabular}

\section{Results}

Figure 1 shows age specific death rates among women in London during 1901-10, expressed as a percentage of the rates in England and Wales. Among girls under 5 London rates are above the national average; they are $20 \%$ above in those aged 2 to 3 years. With increasing age the rates for girls and women fall sharply so that from 15 to 34 years they are well below the average, being $17 \%$ below in those aged 20 to 24 . Among older women rates rise and are again above the average. Among men the overall pattern is similar to that in women, with lower rates in young adults; but only at ages 15-24 are London rates below the national average. Analysis of death rates for the previous decade, 1891-1900, shows a similar pattern. ${ }^{21}$

Figure 2 shows death rates in girls under 15 years and in young women aged 15 to 34 years in the counties of England and Wales during 1901-10. As expected the rates are related. Counties with lower death rates in girls, which are mostly those in the south and east, have lower rates in young women, and vice versa. London is exceptional. The high death rate in girls is disproportionate to the low rate in young women.

The main causes of death of young women in London, and the relation of London death rates to national rates, are shown in table I. London women

TABLE I-Leading causes of death among women aged 15-34 years in London, 1901-10

\begin{tabular}{lrcc}
\hline & \multicolumn{2}{c}{ Death rate per million } & $\begin{array}{c}\text { London rates as } \\
\text { percentage of }\end{array}$ \\
\cline { 2 - 4 } Cause of death & London & England and Wales & England and Wales \\
\hline Tuberculosis & 1231 & 1485 & 83 \\
Childbirth & 288 & 386 & 75 \\
Pneumonia & 202 & 236 & 85 \\
Cancer & 131 & 97 & 134 \\
Violence & 130 & 120 & 108 \\
Enteric fever & 71 & 98 & 72 \\
Septic diseases & 69 & 40 & 174 \\
Rheumatic fever & 57 & 65 & 87 \\
All other causes & 1300 & 1381 & 94 \\
\hline
\end{tabular}

had low death rates from tuberculosis, which was the commonest cause of death, and from childbirth, pneumonia, enteric fever, and rheumatic fever. They had high rates from cancer, violence, and septic diseases. The data do not allow cancer deaths to be analysed by site. Analysis of death rates during the previous decade, 1891-1900, shows a similar pattern, with low death rates for tuberculosis and the major infectious diseases and for childbirth, and high rates for cancer and violent death. ${ }^{2}$

The registrar general analysed deaths from lobar pneumonia in London women during the five years $1906-10 .{ }^{18}$ Table II shows that rates in young women were around $20 \%$ below the average, whereas for all other ages they were above average.

Figure 3 relates the proportion of women in London at each age to the proportion in the population of England and Wales. There was a large excess of young women in relation to girls and older women. Neither the other large towns (county boroughs) or small towns (other urban districts) showed a similar pattern. The

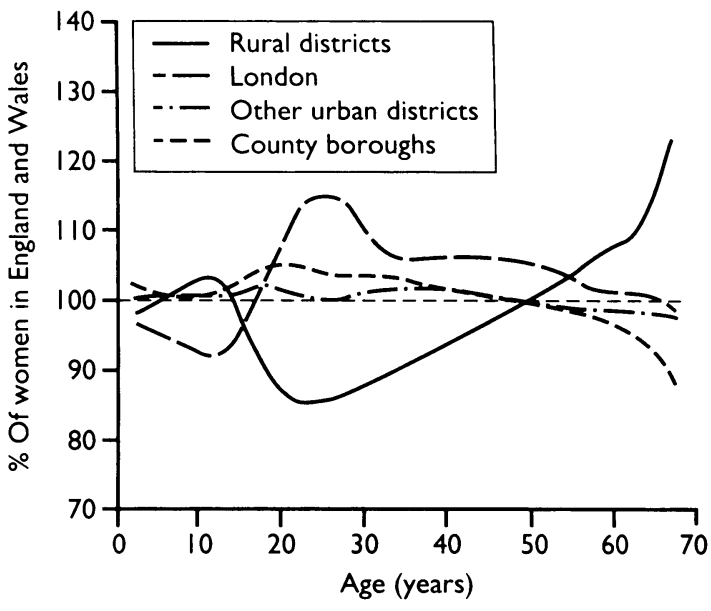

FIG 3-Age distribution of women in London, county boroughs (large towns), other urban districts (small towns), and rural districts compared with that of women in England and Wales

age distribution in rural districts was the reverse of that in London, with an excess of girls and older women but a deficiency of young women.

Table III shows the place of birth of all women aged 20-34 living in London at the time of the census in $1911 .^{18}$ Of 669410 women only $63 \%$ were born in London; 22\% were born elsewhere in southern England-that is, in the counties south of a line between the Severn estuary and the Wash. The remainder came from elsewhere in Britain or from overseas.

Out of some 882605 young women in London in 1911,507967 (58\%) were employed (table IV), 154491 in indoor domestic service. Girls born in London were averse to entering resident domestic service, and most servants came from the southern rural counties. Few married women were employed, and most women who were not employed were married. Women's age at marriage in London was similar to the national average. One per cent of London women under $20,22 \%$ of women aged 20 to 24 , and $51 \%$ of women aged 25 to 29 were married. The comparable figures for England and Wales are $1 \%, 24 \%$, and $56 \%$.

\section{Discussion}

At the beginning of this century young women in London had remarkably low death rates (tables I and II). These low rates contrasted with the high rates in girls under 15 (figs 1 and 2). At that time the death rates of London children from common infections, including measles and whooping cough, were the highest of any county in England and Wales. Booth described London children in the poorer classes as "underfed, ill-clad, badly lodged, and poorly born."22 They lived where "the main streets, narrow at best, branch off into others narrower still; and these again into a labyrinth of blind alleys, courts and lanes; all dirty, foul-smelling, and littered with garbage of every kind. The houses are old, damp and dilapidated." ${ }^{23}$

Two possible explanations for the good health of young women in London are migration and domestic service. Dwindling rural industries, the depression of agriculture, and low wages in the villages encouraged young people to migrate to the towns. Those in the southern counties went in large numbers to London, attracted by the opportunities for employment and the high wages. The usual age of migration was between 15 and 30 , and more young women than young men went to London, largely because of the demand for domestic servants. This was reflected in the relative excess of young women in London's population (fig 3).

Booth described migration into London. "The 
TABLE III - Place of birth of women aged 20-34 years living in London in 1911

\begin{tabular}{lr}
\hline Place of birth & $\begin{array}{c}\text { No (\%) } \\
\text { of women }\end{array}$ \\
\hline London & $422400(63)$ \\
Southern England & $146246(22)$ \\
Northern England & $32669(5)$ \\
Wales & $6532(1)$ \\
Scotland & $8842(1)$ \\
Ireland & $9877(1)$ \\
Abroad & $37380(6)$ \\
Unknown & $5464(1)$ \\
Total & 669410 \\
\hline
\end{tabular}

TABLE IV - Numbers of women aged 15-34 years in employment or married in London in 1911

\begin{tabular}{lc}
\hline & No of women \\
\hline All women aged & \\
$15-34$ & 882605 \\
Employed & 507967 \\
In domestic & 154491 \\
$\quad$ service & \multicolumn{2}{c}{38893} \\
$\quad$ Married & 374638 \\
Not employed & \multicolumn{2}{c}{367088} \\
$\quad$ Married & 2670 \\
\hline
\end{tabular}

countrymen drawn in [to London] are mainly the cream of the youth of the villages, travelling not so often vaguely in search of work as definitely to seek a known economic advantage. . . . It is the result of the conditions of life in great towns, and especially in this the greatest town of all, that muscular strength and energy get gradually used up; the second generation of Londoners is of lower physique and has less power of persistent work than the first; and the third generation (where it exists) is lower than the second. ... London is to a great extent nourished by the literal consumption of bone and sinew from the country; by the absorption every year of large numbers of persons of stronger physique, who leaven the whole mass, largely direct the industries, raise the standard of health and comfort, and keep up the rate of growth of the great city only to give place in their turn to a fresh set of recruits, after London life for one or two generations has reduced them to the level of those among whom they live." 22

More than $20 \%$ of the young women in London at the 1911 census were born in the fertile agricultural counties in southern England (table III) and would have had good nutrition in utero and during childhood. An unknown percentage of those born in London would have had mothers who were born in these counties. Experience in the Dutch famine in 1944 showed that undernutrition of a female in utero impairs her ability to sustain fetal growth in her own offspring. ${ }^{24}$ The good nutrition of young women who came to London from the countryside may have benefited not only their children but their children's children.

Thirty per cent of young women in employment in London were in domestic service at the time of the 1911 census (table IV). Women generally left domestic service when they married, and an unknown percentage of the young women who were married would have previously been in domestic service. Young women who went into domestic service would have had good nutrition in the years before their marriage and pregnancies. ${ }^{25}$ The food given to domestic servants was

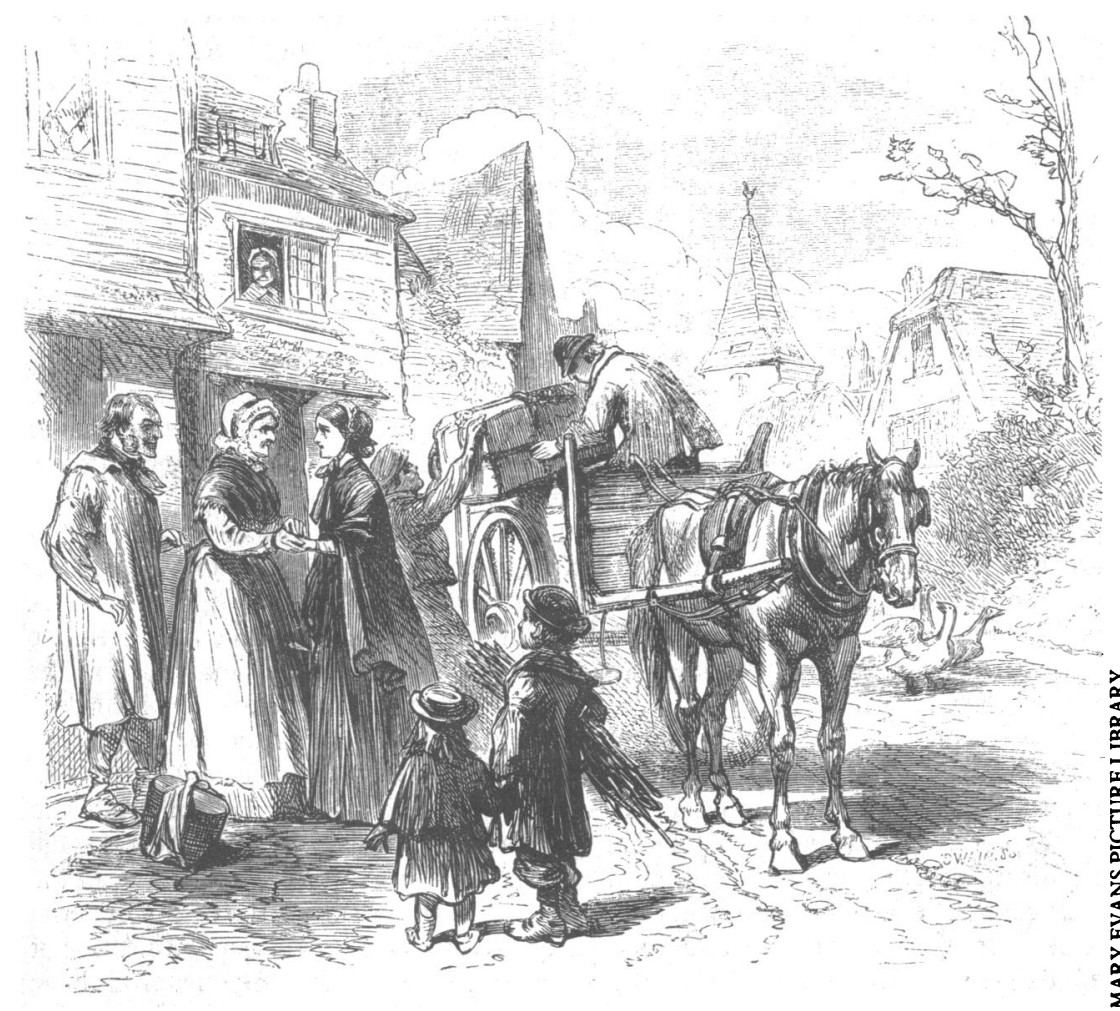

Girls leaving the country to go into service were among "the cream of the youth of the village, travelling . . definitely to seek a known economic advantage"; they made up over a fifth of the young women in London at the 1911 census "usually very good, and in all but very rare cases greatly superior to that obtainable by the other members of the working class families from which servants are drawn." ${ }^{26}$ When members of the Domestic Servants Society, formed in 1912, applied for health insurance, they were found to be more healthy than any other group of women workers. ${ }^{27}$

The registrar general questioned whether the low death rates in young women in London at the turn of the century were not partly due to those who were born in other parts of the country returning home when they became ill. He concluded, however, that though this could not be wholly discounted for tuberculosis it could not apply to lobar pneumonia (table II), "sufferers from which are struck down too suddenly as a rule to return to distant homes before their death." 17

During routine examinations of London school children around the time of the first world war the girls were more likely than boys to be classed as having "excellent nutrition." ${ }^{28}$ This contrasted with findings in industrial towns, where boys were fed better than girls. In Hull, for example, during 1913 "the proportion of boys classed as enjoying 'good' nutrition far exceeded the proportion of girls so classed . . . by a factor of five among the 10 year old children." ${ }^{29}$ Girls in London seemed to escape the unequal division of the families' food that occurred in industrial Britain because of the emphasis on male manual work that still occurs elsewhere in the world, in patrilineal societies and in societies where veneration of ancestors is centred on men.

We conclude that the health of young women in London at the beginning of the century was unusually good because many were born in the fertile agricultural counties of southern England or had mothers who were born in these counties. They therefore had good nutrition in fetal life and infancy. Among children in London there was no preferential feeding of boys. Girls who went into domestic service were unusually well fed in adolescence and as young adults. The evidence that the nutrition and health of mothers has a profound effect on rates of cardiovascular disease in the next generation rests on studies that link the fetal and infant growth of individuals with the occurrence of cardiovascular disease and its risk factors in their adult lives. ${ }^{3.13}$ The ecological findings in London add little to this evidence. They do, however, give an insight into why young women in London at the beginning of this century were healthy and well nourished and had children who now have low death rates from ischaemic heart disease and stroke.

1 Registrar general's statistical review of England and Wales. Part I: tables, medical. London: HMSO, 1880 and following years.

Gardner MJ Winter PD, Barker DJP. Atlas of mortality from selected diseases in England and Wales 1968-78. Chichester: Wiley, 1983.

3 Barker DJP, Winter PD, Osmond C, Margetts B, Simmonds SJ. Weight in infancy and death from ischaemic heart disease. Lancet 1989;ii:577-80.

4 Barker DJP, Osmond C, Simmonds SJ, Wield GA. The relation of head circumference and thinness at birth to death from cardiovascular disease in adult life. $B M \mathcal{J}$ (in press)

5 Hales CN, Barker DJP. Type 2 (non-insulin-dependent) diabetes mellitus: the thrifty phenotype hypothesis. Diabetologia 1992;35:595-601.

6 Phipps K, Barker DJP, Hales CN, Fall CHD, Osmond C, Clark PMS. Feta growth and impaired glucose tolerance in men and women. Diabetologia (in press).

Barker DJP, Bull AR, Osmond C, Simmonds SJ. Fetal and placental size an risk of hypertension in adult life. $B M \mathcal{F}$ 1990;301:259-62.

8 Law CM, de Swiet M, Osmond C, Fayers PM, Barker DJP, Cruddas AM, et al. The initiation of hypertension in utero and its amplification throughout life. $B M \mathcal{F}$ (in press).

9 Barker DJP, Meade TW, Fall CHD, Lee A, Osmond C, Phipps K, et al. Relation of fetal and infant growth to plasma fibrinogen and factor VI concentration of

10 Fall CHD, Barker DJP, Osmond C, Winter PD, Clark PMS, Hales CN. Relation of infant feeding to adult serum cholesterol concentration and death from ischaemic heart disease. $B M \mathcal{F}$ 1992;304:801-5.

11 Barker DJP, Hales CN, Fall CHD, Osmond C, Phipps K, Clark PMS Type 2 (non-insulin-dependent) diabetes mellitus, hypertension and hyperlipidaemia (syndrome $\mathrm{X}$ ): relation to reduced fetal growth. Diabetologia (in press)

12 Law CM, Barker DJP, Osmond C, Fall CHD, Simmonds SJ. Early growth and abdominal fatness in adult life. $f$ Epidemiol Community Health 1992;46:184-6. 
13 Barker DJP, ed. Fetal and infant origins of adult disease. London: British Medical Journal, 1992

14 Campbell JM, Cameron D, Jones DM. High maternal mortality in certain areas. London: HMSO, 1932. (Ministry of Health reports on public health and medical subjects No 68.)

15 Local Government Board. Thirty-ninth annual report 1909-10. Supplement on infant and child mortality. London: HMSO, 1910

16 Booth C. Life and labour of the people in London. First series: poverty. Volume 1. East, central and south London. London: MacMillan, 1902.

17 Registrar General of Births, Deaths, and Marriages in England and Wales. Supplement to the seventy fifth annual report. Pant III, registration summary tables 1901-10. London: HMSO, 1919.

18 Registrar General of Births, Deaths, and Marriages in England and Wales. Seventy fourth annual report (1911). London: HMSO, 1913.

19 Census of England and Wales 1911. Volume VII. Ages and condition as to marriage. London: HMSO, 1913.

20 Census of England and Wales 1911. Volume IX. Birthplaces. London: HMSO, 913.

21 Registrar General of Births, Deaths, and Marriages in England and Wales. Supplement to the sixty fifth annual report. Part I, registration summary tables 1891-1900. London: HMSO, 1907.
22 Booth C. Life and labour of the people in London. First series: poverty in London. Volume 3. Blocks of buildings, schools and immigration. London: MacMillan, 1902.

23 Booth C. Life and labour of the people in London. Second series: industry. Volume 5. Comparisons, survey and conclusions. London: MacMillan, 1903.

24 Lumey LH. Decreased birthweights in infants after maternal in utero exposure to the Dutch famine of 1944-1945. Pediatric and Perinatal Epidemiology 1992;6:240-53

25 Ariouat J, Barker DJP. The dici of girls and young women at the beginning of the century, Nutrition and Health (in press).

26 Booth C. Life and labour of the people in London. Second series: industry in London. Volume 4. Public professional and domestic service, unsuccessful classes. London: MacMillan, 1903.

27 The new survey of London life and labour. Volume II. London industries. London: P S King and Son, 1931.

28 London County Council. Annual report of council 1915-19. Volume III, public health. London: LCC, 1919.

29 Wall R. Some inequalities in the raising of boys and girls in nineteenth and twentieth century England and Wales. Cambridge: Cambridge Group for the History of Population and Social Structure, 1990.

\title{
Socioeconomic differentials in mortality: evidence from Glasgow graveyards
}

\author{
George Davey Smith, Douglas Carroll, Sandra Rankin, David Rowan
}

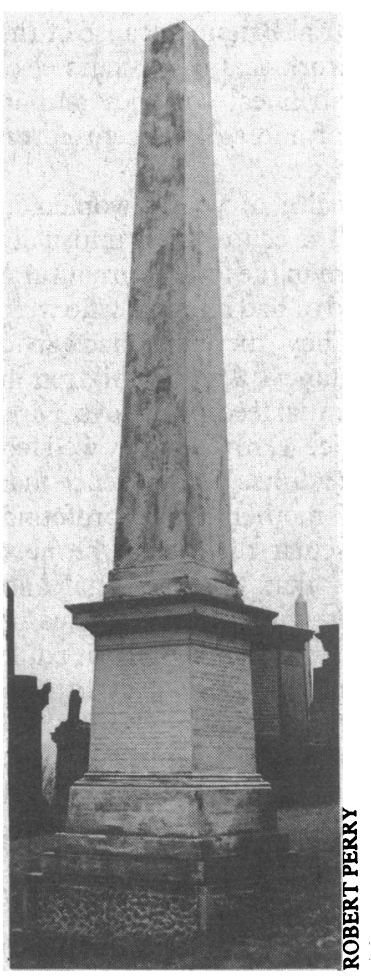

Department of Public Health, University of Glasgow, Glasgow G12 8RZ

George Davey Smith, senior lecturer in public health and epidemiology

Department of Psychology, Glasgow Polytechnic, Glasgow G4 0BA

Douglas Carroll, professor Sandra Rankin, research associate

David Rowan, research associate

Correspondence to: Dr Davey Smith.

BMF 1992;305:1554-7

\section{Introduction}

In 1842 the average age of death for "gentlemen and persons engaged in the professions and their families" was 45 years, for "tradesmen and their families" it was 26 years, whereas for "mechanics, servants and labourers and their families" it was only 16 years. ${ }^{1}$ In 1904, the report of the interdepartmental committee on physical deterioration noted the paucity of data available on social status and mortality, commenting in particular on the failure of the registrar general's routine statistical returns in this regard. ${ }^{2}$ Responding in part to this demand, T H C Stevenson, one time superintendent of statistics at the General Register Office, analysed mortality for the years 1910-2 according to eight occupationally based social class groups. ${ }^{3}$ He noted that this was unsatisfactory, since it was too dependent on classifications according to industry, with "all grades of worker, master and man, skilled and unskilled" grouped together in some cases. In 1921 "a determined attempt was made to purge the occupational classification of its industrial taint," it is from the reports of social class differentials in mortality around the 1921 census $^{4}$ that the continuing series of decennial supplements on occupational mortality are generally dated.'

Since 1921 these reports have revealed a more or less consistent pattern of risk in all cause mortality increasing from the professional groups in social class I to the unskilled labourers in social class V. ${ }^{4-10}$ More recent studies focusing on non-occupational measures of material wellbeing, such as housing tenure and car ownership, have generally been able to differentiate mortality risk better than analysis by social class alone. ${ }^{11}$ Indices such as these are not recorded on death certificates, so mortality rates cannot be computed by comparing death registrations (numerator) to census figures for the population at risk (denominator). Showing large differentials in mortality according to asset based measures of available income has therefore depended on following up large cohorts ${ }^{12} 1^{13}-$ but such data cannot be obtained for earlier periods.

One way the issue can be explored is through commemorative obelisks of a uniform design (figure) found in burial grounds in Glasgow. The height of these obelisks varies greatly, yet their shape remains standard. As the height would influence the cost of the obelisk, it is reasonable to assume that more wealthy decedents would be commemorated by taller obelisks. We set out to determine whether better socioeconomic status, indexed by taller obelisks, was associated with greater longevity during the period 1801-1920.

\section{Method}

A standard form of obelisk is a common marker of graves in the graveyards of Glasgow. All such obelisks were inspected in eight graveyards in Glasgow: the Cathedral, Eastern, Southern, and Western Necropolises, and Sighthill, Vennel, Rutherglen, and Craigton graveyards. From the obelisk, details were taken of the year of death and age at death of the first generation of the family commemorated by the obelisk. In general the obelisk would have been erected in memory of the first deceased of these; their year of death was taken to be the year of construction of the obelisk. Some obelisks commemorated only a male or female family elder; from these only one set of data were recorded. Only people dying before 1921 were included in this study as the registrar general started reporting death rates by five social class groups for the period around the 1921 census. If one of a couple commemorated on an obelisk died before 1921 and one after, only data for the former were used.

If data were incomplete - on some obelisks the date of death, but not age at death, was recorded - a record of the burial was consulted. ${ }^{14}$ Even so, complete data could not be obtained for 60 people. The inscriptions were illegible on 95 obelisks, usually because of weathering, although some could not be read because they had collapsed with the inscription facing downwards and could not be turned over.

The height of each obelisk was measured with a set of chimney sweep rods, each $90 \mathrm{~cm}$ long, with gradations added. Height was measured from the base of the plinth to the crest of the pyramidal top piece, to the nearest $5 \mathrm{~cm}$. The principal material in the obelisk - granite, marble, or sandstone - was recorded. Four obelisks made of different materials (three iron, one concrete) were not included in the study. Granite was, and is, the most expensive of these materials and sandstone the least expensive ( $R$ Taylor, personal communication). ${ }^{15}$ The price differential between the materials depends on the exact source of the material and has varied over time, so no precise quantification of costs can be made. Therefore the three materials have been simply treated as giving an ordering of the cost for each obelisk at any given height.

The relations between continuous variables were 